\title{
Kinetic study of solid phase demineralization by weak acids in one-step enzymatic bio-refinery of shrimp cuticles
}

\author{
Baron Regis ${ }^{1,}{ }^{*}$, Socol Marius ${ }^{1}$, Arhaliass A. ${ }^{4}$, Bruzac Sandrine ${ }^{1}$, Le Roux Karine ${ }^{3}$, \\ Rodriguez Del Pino J. ${ }^{1}$, Bergé Jean-Pascal ${ }^{1}$, Kaas Raymond ${ }^{2}$
}

\author{
${ }^{1}$ Ifremer, Biorafhe, rue de l'Île d'Yeu, BP21105, 44311 Nantes cedex 03, France \\ 2 Ifremer, PBA, rue de l'Île d'Yeu, BP21105, 44311 Nantes cedex 03, France \\ ${ }^{3}$ Ynsect, rue de l'île d'Yeu, BP21105, 44311 Nantes cedex 03, France \\ ${ }^{4}$ Université de Nantes - GEPEA UMR CNRS 6144, CRTT, boulevard de I'Université, 44600 Saint- \\ Nazaire cedex, France \\ * Corresponding author : Regis Baron, Fax: +33 240374071 ; email address : $\underline{\text { rbaron@ifremer.fr }}$
}

\begin{abstract}
:
We describe a one-step bio-refinery process for shrimp composites by-products. Its originality lies in a simple rapid $(6 \mathrm{~h})$ biotechnological cuticle fragmentation process that recovers all major compounds (chitins, peptides and minerals in particular calcium). The process consists of a controlled exogenous enzymatic proteolysis in a food-grade acidic medium allowing chitin purification (solid phase), and recovery of peptides and minerals (liquid phase). At a pH of between 3.5 and 4, protease activity is effective, and peptides are preserved. Solid phase demineralization kinetics were followed for phosphoric, hydrochloric, acetic, formic and citric acids with pKa ranging from 2.1 to 4.76. Formic acid met the initial aim of (i) $99 \%$ of demineralization yield and (ii) $95 \%$ deproteinization yield at a pH close to 3.5 and a molar ratio of 1.5. The proposed one-step process is proven to be efficient. To formalize the necessary elements for the future optimization of the process, two models to predict shell demineralization kinetics were studied, one based on simplified physical considerations and a second empirical one. The first model did not accurately describe the kinetics for times exceeding 30 minutes, the empirical one performed adequately.
\end{abstract}




\section{Graphical abstract :}

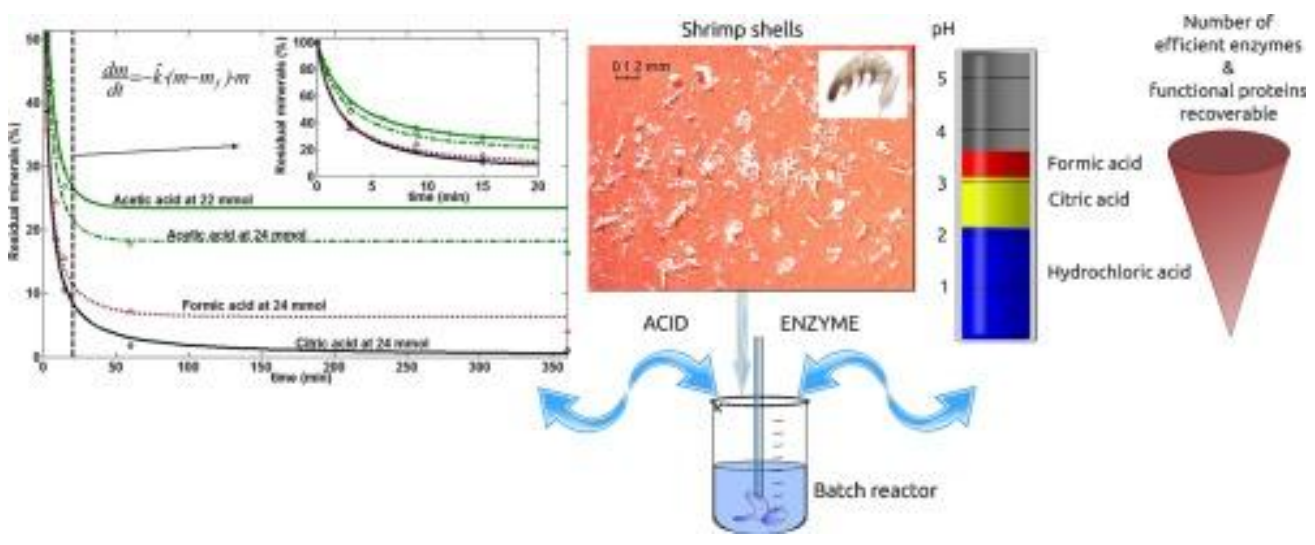

\section{Highlights}

- Formic acid met the initial aim of $99 \%$ demineralization yield and $95 \%$ deproteinization yield at a $\mathrm{pH}$ close to 3.5 and a molar ratio of 1.5. The proposed one-step process proved efficient. An effective empirical model of demineralization kinetics was defined.

Keywords : bio-refinery, acidic enzymatic proteolysis, shrimp cuticles, demineralization kinetics and modeling 


\section{Introduction:}

World consumption of crustaceans, especially shrimps, has soared in the last decades. Annual world production of shrimps in 2012 was estimated by the F.A.O. [1] at more than 6 Mt with Litopenaeus vannamei accounting for some $60 \%$ of the total. In recent decades the consumption of peeled shrimps has experienced exceptional growth, generating a large amount of waste, about $50 \%$ by weight of whole shrimps [2], meat recovery accounting for only about 50\% (w/w). Shrimp cuticle (shell) represents almost 30\% (w/w) of this waste. Cuticle dry matter is $25-30 \%$. Shrimp cuticle is a natural composite with a complex spatial organization in which proteins are interconnected with chitin macromolecules and with minerals [3-5]. Proteins amount to about $40 \%$ of the shrimp cuticle dry weight [6], minerals and chitin representing the other major fractions [7]. The economic balance of this process can be improved by fully utilizing chitin (around 28\% of the dry matter). Peptides and pigments such as astaxanthin [8-16] could be also developed. Chitin and its derivatives, especially chitosan, its deacetylated derivative, have specific properties (highly basic polysaccharides, polyelectrolyte behavior, ability to form films, solubility in various media, metal chelation, etc). These properties make them useful for many applications [17-20] in various sectors such as food [21], cosmetics and biomaterials [22]. Chitin is a natural polysaccharide synthesized by a great number of living organisms [23]: the amount produced annually throughout the world shows it to be the most abundant renewable natural resource after cellulose [24].

Several techniques to purify chitin from various crustaceans have been described $[17,18,25$, 26]. In all cases, the compounds associated with chitin have to be separated. A solid-phase demineralization step for chitin purification is needed, possibly together with the elimination of other components. This step is usually performed in an acid medium. Kinetic reactions associated with mineral solubilization are described in the literature mainly for pure powders 
and strong acids [27], but reactions for more complex, structured solid matrices are underresearched [28]. Influences related to the type of acid and the reaction environment are not yet adequately formalized. Yet prediction of kinetics is essential for good process optimization [29]. Generally, demineralization is followed by water rinsing, and in a second step by deproteinization with strong bases [30]. All these extraction steps may damage chitin through uncontrolled depolymerization and deacetylation [31].

Proteins or protein derivatives (peptides) are strongly denatured at low $\mathrm{pH}[32,33]$. For this reason the classical chemical purification of chitin cannot be envisaged as a bio-refinery process.

As an alternative efforts have been made towards reducing chemical treatments in more ecofriendly processes [34-36]. Enzymatic hydrolysis of crustacean shells was used in an alternative bio-refinery approach in order to recover simultaneously from edible proteins, peptides and chitin from whole biomass. Enzymatic reactions linked to the deproteinization step can be induced by bacterial fermentation [25, 35, 37-39] or by exogenous proteolytic enzyme treatment $[11,15,36]$. A growing number of studies show that the extraction of shell compounds can be accelerated by the joint use of sonication [40-43].

All these bio-refinery treatments involve either substantial consumption of water in a two-step bio-refinery process in the case of exogenous enzymatic hydrolysis, or too long process times, resulting generally in insufficient chitin purification rates and a need for further fermentation treatment. These constraints form a major obstacle to industrial development.

We have proposed a novel method based on exogenous enzymatic proteolysis in acid conditions in a one-step demineralization and deproteinization process taking less than $6 \mathrm{~h}$ [2, 6, 44]. Here, we call “one-step process” the simultaneous implementation of two different reactions, namely demineralization and deproteinization, in the same chemical environment, enabling proteolysis in acidic media, and without intermediate rinsing. In previous work we 
investigated a pepsin/phosphoric-acid mixture $\left(40{ }^{\circ} \mathrm{C}\right.$, pH after $6 \mathrm{~h}=1.9$, ratio of $10 \%$ of enzyme versus dry matter, $2.7 \mathrm{M}$ acid solution, $50 \mathrm{ml}$ of reacting volume) in solution under excess acid conditions [2]. Deproteinization yields exceeding $95 \%$, combined with demineralization yields exceeding $99 \%$ were obtained in 6 h, indicating a satisfactory degree of purity of chitin (> 92\%) for an enzymatic process. Intermediate filtrations and separations are avoided. Reaction times and water volumes are reduced.

Reducing the acidity of the medium should preserve the solubilized protein components. Neutralization in the aqueous phase of the step could even be omitted if the $\mathrm{pH}$ was close to 3.5 - 4.0. This would both reduce the environmental impact of the proposed bio-refining process, and increase its profitability. Demineralization and deproteinization performance obtained within $6 \mathrm{~h}$ in the study of Le Roux et al. [2, 6, 44] were taken as targets to be reached or exceeded during our study, while seeking to raise the $\mathrm{pH}$ of the solution. According to [2, 44], the initial size of the solid pieces of crushed shells affects demineralization and deproteinization kinetics: these processes are faster as size is smaller, but the rate increase is negligible below $1 \mathrm{~mm}$. We analyzed conditions and parameters (acid and water quantities, type of acid, temperature, $\mathrm{pH}$, and solution corresponding to the enzyme $\mathrm{pH}$ activity range), needed to collect information to optimize the new alternative solution. Appropriate information for choosing an acid in a non-exhaustive list of five acids was collected, and the best experimental conditions defined for a solid particle size range between 0.5 and $1 \mathrm{~mm}$. To corroborate the decoupling observed by [2] between the kinetics of demineralization and the kinetics of protein removal, an analysis in the presence and absence of the enzyme, in conditions favorable to deproteinization, is proposed for two other acids.

Our earlier work [2] focused on the use of phosphoric acid, which we compared with hydrochloric acid typically used in conventional chemical methods. We then studied the behavior of the process when a weak acid conventionally used in food was added: acetic acid 
and formic acid. Another organic acid with a low $p K_{a}$ was also studied: citric acid. We compared the kinetics of demineralization for five acids under conditions close to stoichiometric. The effect of molar ratio and reaction volume were then analyzed for acetic acid and formic acid.

Based on the reaction with acetic acid, we formalized the kinetics obtained. First, the models were based on knowledge reported in the literature (main reaction stoichiometric equations and simplified knowledge model described by Fusi et al. [27]). Secondly, the results from the knowledge models were compared with an empirical model proposed by the authors. This formalization aimed to offer a suitable tool for later digital process optimization. We made a parametric adaptation of the empirical model using all the results obtained in this work.

\section{Material and methods}

\section{Raw materials and sample preparation}

Shrimps (Litopenaeus vannamei), farmed in Ecuador (Omarsa sa) and frozen HOSO (head on shell on) in packs of $2.5 \mathrm{~kg}$, were used as raw material. Mean weight per shrimp was $13.3 \pm 0.8 \mathrm{~g}$ (70 - 80 shrimps per kilogram). The shrimps were thawed (for $24 \mathrm{~h}$ at ambient temperature) and manually peeled. The cuticles were washed, dried for $24 \mathrm{~h}$ in a controlled oven at $30^{\circ} \mathrm{C}$ (Thirode), with an air velocity around the cuticles of $0.5 \mathrm{~m} \mathrm{~s}^{-1}$, and relative humidity $50 \%$, ground to powder for 1 minute in a blender (model 80106 Waring), sized using a sieve shaker (AS200 Basic, Retsch) and stored in $200 \pm 20 \mathrm{~g}$ lots at $-20^{\circ} \mathrm{C}$ under vacuum. The ground size distribution range was between 0.5-1 mm. Identical assays made at different times yielded similar results, indicating that content was not damaged in time. The composition of the 0.5-1 mm ground cuticle [2], after mild drying, was : $11.2 \pm 2.0 \%$ water, $23.3 \pm 3.6 \%$ minerals ( $1.17 \mathrm{~g}$ for $5 \mathrm{~g}$ of raw material), $35.6 \pm 2.0 \%$ proteins $(\sim 1.78 \mathrm{~g}$ 
for $5 \mathrm{~g}$ of raw material), $25.0 \pm 3.0 \%$ chitin ( $1.25 \mathrm{~g}$ for $5 \mathrm{~g}$ of raw material), and $\sim 5 \%$ others (fatty acids, glycosides, pigments).

All the acids were purchased from Sigma-Aldrich (Saint-Quentin Fallavier, France). The enzyme acid stable protease (ASP; 3000 SAPU / g; conditions:. $30-60^{\circ} \mathrm{C}$ and $\mathrm{pH}=[2.0-$ 4.0], Bio-Cat Inc.) was used for most of the experiments, with an enzyme / dry raw material ratio of $1: 10$

Solution pH was measured with an analytical pHmeter (CyberScan pH/Ion 510, Eutech Instruments) and with an electrolytic pH electrode (InLab Expert Pro, Mettler Toledo).

\section{Characterization of materials}

Ash content was measured gravimetrically after incinerating the sample in an aluminum container $\left(12 \mathrm{~h}\right.$ at $550^{\circ} \mathrm{C}$ [45]) to quantify minerals. Filtered solutions were first freeze-dried (Pilote, Cryotec) before applying the gravimetric method. According to Raabe et al. [3], calcium carbonate is the main form of the minerals from shrimp shells $(>90 \%$ of total inorganic matter). Verification was carried out by scanning electron microscopy coupled with energy dispersive X-ray (EVO-40 EP, SEM- Zeiss).

Dry weight was measured by weighing samples after drying in an oven at $105^{\circ} \mathrm{C}$ for $24 \mathrm{~h}$ [45].

Percentages of residual minerals $(R M)$ were given by :

$$
R M=100 \times \frac{W_{a s h}}{W_{0}}
$$

with $W_{\text {ash }}$ the ash quantity remaining in residual solids found in $5 \mathrm{~g}$ of cuticle and $W_{0}$ the initial ash quantity found in $5 \mathrm{~g}$ of cuticle before acid treatment $\left(W_{0}=1.17 \mathrm{~g}\right)$. Demineralization yields $(D Y)$ were :

$D Y=100-R M$ 
The protein content is obtained by summing the concentrations of the various amino acids present. This method is the most consistent in terms of comprehensive mass balance [2]. This analysis requires $10 \mathrm{mg}$ of powder, hydrolyzed in $6 \mathrm{M}$ hydrochloric acid for $24 \mathrm{~h}$.

Amino acid analysis was performed using the EZ:fast ${ }^{\mathrm{TM}}$ procedure (Phenomenex, Torrance, CA, USA), consisting of a solid-phase extraction step followed by derivatization and liquid/liquid extraction. Amino acids were quantified by gas chromatography (GC-FID, Perkin Elmer Autosystem XL, Waltham, MA, USA) using the method described by Valente et al. [46].

Residual proteins (RP) and deproteinization yields (PY) were expressed as:

$$
R P=\frac{\sum A A_{t}}{\sum A A_{0}}
$$

with $A A_{t}$ : amino acids at time $t$ and $A A_{0}$ : initial quantity of amino acids.

Deproteinization yields are given by :

$$
P Y=100-R P
$$

\section{Experimental setup}

For cuticle demineralization experiments, a fixed initial weight of $5 \mathrm{~g}$ of dried shrimp cuticles was used in a preset volume of acid solution $(50 \mathrm{~mL})$. Several experiments were performed at $250 \mathrm{~mL}$ and $1000 \mathrm{~mL}$ to assess the volume influence. All the reactions were run in beakers (100-2000 mL) under constant continuous stirring (300 rpm) with magnetic stirrers. Temperature was controlled with thermostatic plates.

Owing to small reactor volumes (often $50 \mathrm{~mL}$ ), each time point corresponded to a specific test with $5.0 \mathrm{~g}$ of cuticle. The whole reaction volume (solid and liquid phases) was collected to ensure the consistency and accuracy of the results. All the solids were removed by filtering with Nylon filters of mesh size 300 microns. Reaction on solids was neutralized by rinsing with $500 \mathrm{~mL}$ of distilled water. 
To reduce the number of experiments without compromising information gain, the time sampling protocol was selected on the basis of previously acquired knowledge [2]. First, in order to assess the effect of temperature, three temperatures $\left(20,30\right.$ and $\left.40^{\circ} \mathrm{C}\right)$ and three times (9, 15 and 360 minutes) were studied on acetic and formic acid. A comparison of the degree of demineralization in the presence and absence of enzyme (ASP enzyme) was made on the basis of the same time sampling procedure for a temperature of $40{ }^{\circ} \mathrm{C}$ For each acid, five beakers were started together and stopped one by one for analysis after 3, 9, 15, 60 and 360 minutes.

For modeling, the kinetics were then refined (acetic acid) by adding six new time points (0.5, 1, 2, 6, 12 and 20 minutes). Experiments were conducted at $20^{\circ} \mathrm{C}$ (i) for better control of temperature, and (ii) to lengthen reaction time so as to be able to add more time points.

Among sixty four experiments, forty five where run three times (see Supplemental Table 1). One way analysis of variance was used to determine the variables with significant influence. Based on more then 30 repeats, the relative error of demineralization results proved constant, ranging around $10 \%$.

\section{Basic equation and stochiometry}

Calcium carbonate being the major mineral form in shrimp cuticle, the main demineralization reaction is:

$$
\begin{aligned}
& \mathrm{CH}_{3} \mathrm{COOH}+\mathrm{H}_{2} \mathrm{O} \leftrightarrows \mathrm{CH}_{3} \mathrm{COO}^{-}+\mathrm{H}_{3} \mathrm{O}^{+} \quad \text { with acetic acid, } \\
& \mathrm{pK}_{\mathrm{a} 1}=4.7 ; \quad K_{\mathrm{al}}=\frac{\left[\mathrm{CH}_{3} \mathrm{COO}-\right]\left[\mathrm{H}_{3} \mathrm{O}+\right]}{\left[\mathrm{CH}_{3} \mathrm{COOH}\right]} \\
& \text { or } \mathrm{HCOOH}+\mathrm{H}_{2} \mathrm{O} \leftrightarrows \mathrm{HCOO}^{-}+\mathrm{H}_{3} \mathrm{O}^{+} \quad \text { with formic acid, } \mathrm{pK}_{\mathrm{a}}=3.75 \text {; } \\
& \text { i.e. } \mathrm{CaCO}_{3(\mathrm{~s})}+2 \mathrm{H}_{3} \mathrm{O}^{+} \rightarrow \mathrm{Ca}^{2+}+\mathrm{H}_{2} \mathrm{CO}_{3(\mathrm{aq})}+2 \mathrm{H}_{2} \mathrm{O}
\end{aligned}
$$


The Henderson-Hasselbach equation for the first equilibrium is given by:

$\mathrm{pH}=\mathrm{pK}_{\mathrm{a} 1}+\log _{10}\left(\frac{\left[\mathrm{CH}_{3} \mathrm{COO}-\right]}{\left[\mathrm{CH}_{3} \mathrm{COOH}\right]}\right)$

From the demineralization reaction between calcium carbonate and acid, we define 'molar ratio' as the ratio between the quantity of acid used experimentally and the stoichiometric quantity theoretically needed for total reaction of calcium carbonate.

\section{In silico model}

The first differential equation in this paper describing the time course of hydronium concentration is described in Fusi et al., 2012 [27]. The equation proposed here based on the previous one takes into account the variation of calcium carbonate and its rate of disappearance can be written:

$\frac{d m}{d t}=-\tilde{k} \cdot m^{2 / 3} \cdot\left(10^{-p H}-\varphi\right)^{\gamma}$ with $\tilde{k}=f($ Specific surface, $N, V)$

where $m$ is the mass of remaining calcium carbonate within solids (g), $N$ is the number of assimilated nanospheres at the beginning of the reaction, $V$ is the solution volume (mL), and $\varphi$ is a threshold concentration at which the reaction stops. A spline interpolation was used to define temporal function around $\mathrm{pH}$ measurements and used as input. Parameters $\tilde{k}, \varphi$ and $\gamma$ in Equation 7 were then fitted according to the experimental residual values of minerals.

Equation (7) was tested on a data set obtained with $22 \mathrm{mM}$ acetic acid, close to stoichiometric conditions.

\section{Empirical model}

An empirical equation describing the shrimp cuticle demineralization process was also proposed and then compared with Equation (7).

$\frac{d m}{d t}=-\hat{k} \cdot\left(m-m_{f}\right) \cdot m \quad$ with $m(0)=1.17 \mathrm{~g}$ 
with $m$ the mass of calcium carbonate within solids and $m_{f}$ is the final mineral mass in solids.

Equation (8), previously experimented with success on data with phosphoric acid in excess $(\mathrm{pH}=1.9)$ and high concentration of pepsin [44], has the advantage of using only one output state, the experimental mass, so $\mathrm{pH}$ on-line measurement is no longer necessary.

The mass of minerals, calculated by this model, decreases progressively and stops at the value of parameter $m_{f}$. For $m>>m_{f}$, the kinetics come close to a second order reaction, and with $k$ hat $* m(0)$ the initial 'rate constant'.

\section{Parametrization}

Each parameter adjustment (for Equations (7) and (8)) was performed simultaneously, by the least squares method, to minimize the sum of squared errors (SSE) between predicted values given by the model and experimental data. Models were set up using Matlab 6.5 Simulink Library and fitting was performed with specific user defined subroutines. The Matlab adjustment function is based on a Nelder-Mead algorithm under constraint. Minimum and maximum boundaries were defined for each parameter.

All the experiments performed in this study are described in a Table to be find in the supplemental materials section.

Experiments were structured for an analysis of:

- The effect of enzyme concentration on the kinetics of demineralization at $24 \mathrm{mmol}$ of acid added and $40{ }^{\circ} \mathrm{C}$ with acetic and formic acids,

- $\quad$ The influence of temperature $\left(20,30\right.$ and $\left.40^{\circ} \mathrm{C}\right)$ on the kinetics of demineralization with acetic and formic acids at $24 \mathrm{mmol}$, 
- The comparison of demineralization kinetics of five acids (acetic, formic, phosphoric, citric and hydrochloric acids) at $24 \mathrm{mmol}$ of acid added and $20^{\circ} \mathrm{C}$,

- The detailed monitoring of demineralization kinetics with acetic acid at $22 \mathrm{mmol}$ of acid added and $20^{\circ} \mathrm{C}$,

- The comparison of demineralization kinetics with acetic and formic acids at different molar ratio and $20^{\circ} \mathrm{C}$,

- The influence of molar ratio at $360 \mathrm{~min}$ and $15 \mathrm{~min}$, and $20^{\circ} \mathrm{C}$,

- The influence of the total volume (50 and $250 \mathrm{ml}$ ) on the demineralization kinetics,

- $\quad$ The conditions to obtain demineralization over $99 \%$ at $20{ }^{\circ} \mathrm{C}$ after $360 \mathrm{~min}$ and total volume of $50 \mathrm{~mL}$.

\section{Results and discussions}

The proportion of calcium carbonate in the mineral content was found to be $89.1 \pm 9.9$ \% confirming the results of Raabe et al [3]. On this basis, the authors assumed that ash was a good measure of calcium carbonate content and that the major reaction scheme was described by Equation 5. In our previous work [2,44], no significant effects of pepsin concentration were observed on the demineralization kinetics. We then carried out specific experiments to test the hypothesis that enzymes, which obviously influence the degree of deproteinization, do not significantly affect the degree of demineralization, under less drastic conditions of acidity. Experiments in stoichiometric conditions at $40^{\circ} \mathrm{C}$ with two organic weak acids (acetic and formic acids, $\mathrm{pKa}=4.7$ and 3.7 respectively), with and without acid stable protease (ASP) enzyme were carried out for short times (9 and 15 minutes), and for 6 h (see Table 1). No significant difference was observed in demineralization yields (DY) for either acid, in the 
presence or absence of enzyme. This held for all the different experiment times. The p-values were respectively 0.071 at 9 minutes, $\mathrm{p}=0.801$ at 15 minutes, and $\mathrm{p}=0.291$ at 360 minutes for formic acid. Similar results were obtained for acetic acid for all the times $(p=0.659$ at 9 minutes, $\mathrm{p}=0.8175$ at 15 minutes and $\mathrm{p}=0.726$ at 360 minutes). These results are consistent with previous ones obtained using phosphoric acid [2]. We note that, in these two cases in stoichiometric conditions, deproteinization rate was also insufficient (maximum at $93.9 \%$ for the formic acid/ASP couple).

The influence of temperature on crustacean shell demineralization and deproteinization kinetics with phosphoric acid in excess is described in [4, 42]. These studies show that temperature significantly affects deproteinization during the $6 \mathrm{~h}$ of hydrolysis. On the other hand demineralization kinetics are not significantly affected in the long term (6 $\mathrm{h}$ and longer). For reaction times under $1 \mathrm{~h}$, temperature plays a significant role (results not presented here). Similar verifications were conducted under stoichiometric conditions identical to those of the previous experiments. Results obtained at $20^{\circ} \mathrm{C}, 30^{\circ} \mathrm{C}$ and $40^{\circ} \mathrm{C}$ were compared for the same acid / enzyme couple. The ASP enzyme was chosen to fit $\mathrm{pH}$ conditions associated with the two weak acids tested. The results are given in Table 1 . As previously observed the influence of temperature on the percentage of residual minerals is significant at the beginning of the reaction for formic acid $(\mathrm{p}=0.0001$ at 9 minutes and 0.0002 at 15 minutes. This observation was not made for acetic acid with p-value of 0.1632 at 9 minutes and 0.1787 at 15 minutes). No significant difference was observed for either acid after $6 \mathrm{~h}$ of reaction $(\mathrm{p}=0.8028$ for formic acid and 0.7084 for acetic acid). Hence it appears that temperature has an effect on the reaction rate, during the first minutes, but has no impact on the final demineralization threshold value as previously observed [2].

Given the above results, and to apply the proposed models with greater precision and accuracy, especially for the first minutes of reaction, all subsequent experiments were 
performed at $20^{\circ} \mathrm{C}$ to reduce reaction rate, control temperature more accurately and finally to obtain a more achievable sampling time plan. This temperature was also used to compare the kinetics of demineralization with five acids, and the influence of volume and quantity of acid in excess.

\section{Demineralization kinetics for five acids in stoichiometric conditions and for reaction time of $6 \mathrm{~h}$}

The demineralization kinetics for the five acids tested in this section are shown in Figure 1. Final percentage of residual minerals and $\mathrm{pH}$ solution values are summarized in Table 2. Initial pH values (for a 24 mmole stoichiometric acid solution) before introduction of shrimp cuticle ranged between 0.3 for hydrochloric acid $(\mathrm{HCl})$ and 2.48 for acetic acid. After $6 \mathrm{~h}, \mathrm{pH}$ values were between $2.54(\mathrm{HCl})$ and 5.10 (acetic acid). These final values could be compared to the pKa of the acid.

We first note that the demineralization process was very fast in the first 15 minutes for all the acids and that the reaction rate decreased very markedly thereafter, following the same trend as the $\mathrm{pH}$ (see Fig 2, insert1). For example, formic acid $\mathrm{pH}$ values at $20^{\circ} \mathrm{C}$ after 9 minutes, 15 minutes, 1 hour and 6 hours were 3.89, 3.97, 4.37 and 4.45 respectively. This result is very advantageous for a one-step enzymatic proteolysis process because it permits a relatively stable enzymatic activity throughout the reaction. Interestingly, the behavior of organic acids seems different from that of mineral acids, whether mono- or polyacid. For example, for very close final $\mathrm{pH}$ values, citric acid seems to be more efficient than phosphoric acid. Also, the citric acid solution showed better demineralization performance than hydrochloric acid, and its final $\mathrm{pH}$ was higher than that of the hydrochloric acid solution. The same effect was seen when comparing formic acid with phosphoric acid. 
We note that only one acid (citric acid) reached, in stoichiometric conditions, the objective set for the final residual mineral $(\mathrm{RM})$ percentage $(\sim 1 \%)$, in a $6 \mathrm{~h}$ reaction in the preset solution volume of $50 \mathrm{~mL}$ : for the hydrochloric acid solution, the percentage of residual minerals was 1.4\%. Owing to their higher final $\mathrm{pH}$ values, acetic and formic acids solutions deserve further study: this would allow the use of enzymes with an optimal activity in the $\mathrm{pH}$ interval 3.2-5.

\section{Influence of acid excess and, solution volume on residual minerals percentages}

Results for the two weak acids tested and at final time ( $\mathrm{t}=6$ hours) are shown in Fig. 3; $24 \mathrm{mmol}$ of acid was added, temperature was $20^{\circ} \mathrm{C}$ and no enzyme was added. After $6 \mathrm{~h}$ demineralization yields (DY) and $\mathrm{pH}$ decreased as molar ratio increased. The $\mathrm{pH}$ versus molar ratio relation was relatively linear. By contrast, DY moved more rapidly at the beginning and showed a convex curve, which could be adequately described by a decreasing exponential function.

For both acids (formic and acetic acids), demineralization yields (DY) exceeding 99\% were reached and final $\mathrm{pH}$ was near 3.60. The molar ratios were 1.50 (corresponding to $35 \mathrm{mmol}$ of acid added) and 2.35 (corresponding to $55 \mathrm{mmol}$ of acid added) for formic and acetic acid respectively.

For acetic acid, demineralization yield after 15 minutes (experiment E55 - see in Supplemental Table 1) with a molar ratio of 2.35 was $85.4 \%$ (without replicates). For formic acid, the demineralization yield (DY) at a molar ratio 1.5 and after 15 minutes (experiment E57 - see Table in supplemental materials) was 89.7\% (without replicates.) Hence the molar ratio had an impact on the final value and a small effect on the initial demineralization rate.

The role of the volume of solution was tested in stoichiometric conditions (MR=1.03) for both acids, given that the mineral consumption rate depended on this variable (see Equation 7). Results are grouped in Table 3. By increasing five-fold the volume at $250 \mathrm{~mL}$ for the two 
acids, the demineralization yield (DY) after 15 minutes decreased from $83.6 \%$ to $68.2 \%$, and after $6 \mathrm{~h}$ increased non-significantly $(\mathrm{p}=0.310)$ from $95.9 \pm 0.4 \%$ to $96.3 \pm 0.3 \%$ for formic acid. The final $\mathrm{pH}$ was similar after $6 \mathrm{~h}$ at 4.48 and 4.51 respectively. In this case, the initial rate of demineralization was lowered by the increase in reaction volume, and this increase did not allow any significant gain in the final demineralization..

On increasing the acetic acid solution volume five-fold a significant gain $(\mathrm{p}=0.0028)$ in demineralization yield was obtained after $6 \mathrm{~h}$. The initial demineralization rate decreased at the same time: demineralization (DY) was $73.9 \%$ and $54.8 \%$ for $50 \mathrm{~mL}$ and $250 \mathrm{~mL}$ respectively at 15 minutes. These results agreed with those obtained with formic acid. However, although the residual minerals decreased, we were still far from our goal of residual minerals $<1 \%$. Large reaction volumes are likely to be incompatible with the requirements of industry.

From all the experimental data, we assessed conditions for acidic enzymatic hydrolysis in a 6 h step that would lead to less than $1 \%$ residual minerals for a volume of $50 \mathrm{~mL}$. These conditions are summarized in Table 4. As a function of acid $\mathrm{pK}_{\mathrm{a}}$, different $\mathrm{pH}$ intervals were obtained using minimal quantities of acid and water needed for the cuticle demineralization. Hence for a given enzyme, with a known optimal proteolytic activity $\mathrm{pH}$ range, the acidic conditions can be very easily adapted, offering minimal reactant consumption and maximal bio-molecule recovery. Table 4 also gives results obtained at $40^{\circ} \mathrm{C}$ for all five acids in the presence of ASP enzyme. The optimal pH activity range of this enzyme is broad $(2.5-4.0)$ and compatible with all the acids and conditions tested.

Given the enzyme $\mathrm{pH}$ activity range, 12 commercial proteases kindly provided by industrial partners (BioCat. Inc, DSM, Genecor Int., Novozymes and Valley Research) could be associated with formic acid, six with citric acid and only three with hydrochloric acid. These conditions are applicable to all complex structured by-products containing minerals. 
The results presented in Table 4 demonstrate that only formic acid met, in the presence of the selected enzyme (ASP), all the target criteria we had chosen. Thus for a molar ratio of 1.5 (i.e. $35 \mathrm{mmol}$ of formic acid added to $5.0 \mathrm{~g}$ of shell) at a temperature of $40{ }^{\circ} \mathrm{C}$ and in the presence of the enzyme, after $6 \mathrm{~h}$, demineralization yield exceeded $99 \%$, deproteinization yield was greater than $95 \%$ and $\mathrm{pH}$ was 3.5 .

\section{Kinetic modeling of cuticle demineralization and calcium carbonate powder acid reaction: comparative studies}

The first demineralization kinetics were studied for the acetic acid reaction with $5 \mathrm{~g}$ of shrimp cuticle (corresponding to $1.17 \mathrm{~g}$ of $\mathrm{CaCO}_{3}$ ) and with $1.16 \mathrm{~g}$ of $\mathrm{CaCO}_{3}$ powder, used as a reference. The reaction, in close to stoichiometric conditions, was followed for 20 minutes with regular measurement of the amount of residual minerals. Figure 2 uses the observations of $\mathrm{pH}$ and the chemical balance described by Equations 1 and 2 for estimating a theoretical time course curve of mineral contents. It also presents the levels measured experimentally with their uncertainties. As a first approximation, overall stoichiometry alone does not adequately reflect the phenomena observed (Figure 2A), except for the first minute (see Insert 1, Fig 2A). Firstly, it is likely that we are underestimating additional side reactions such as the various forms of carbonate buffer. Also, the complex structure in the form of a structured nanofibril arrangement interacts with reaction rates. The concept of a confined reaction partly explains the low correspondence using only the main stoichiometric reactions.

\section{Dynamical models for demineralization kinetics}

We went on to evaluate dynamic models in place of stoichiometric equations.

Figure 4 shows curve fitting of acetic acid experimental data using the two proposed models. Fitting parameters by means of Equation 7 with experimental data obtained for the 
demineralization with 22 mmoles of acetic acid at $20^{\circ} \mathrm{C}$ in a volume of $50 \mathrm{~mL}$, gave a global order of reaction of 0.94 . This is in line with non-first order kinetics for a reaction $\mathrm{pH}$ interval going from 2.4 to 5 as proposed by Notari and Sokoloski [44] or Fusi et al [25]:

$$
\frac{d m}{d t}=-1180 \cdot m^{\frac{2}{3}} \cdot\left(10^{-p H}-6.2 \cdot 10^{-10}\right)^{0.94} \quad \text { with } m(0)=1.194 \mathrm{~g}
$$

Equation (9) performs well, as seen in Figure 4, confirmed by a root mean square error (rmse) of low value (0.03) for the prediction of residual minerals for reaction times of less than 20 min. However, the decrease becomes excessive for acetic acid after this time (blue dashed line, Figure 4). An unrealistic value, close to that of total demineralization, is predicted after 90 min, which is to be compared with the experimental data presented in the same figure (black circles). Prediction of model (7), for $24 \mathrm{mmol}$ (not shown on the graph for the sake of clarity), is almost identical to the predictions of Equation (9) obtained for $22 \mathrm{mmol}$ reaction times exceeding $40 \mathrm{~min}$. This model does not take into account the diffusion process of the hydronium ion and other forms mentioned in the work of Fusi et al. [25]. A strong constraint in this model is that it requires an estimation based on experimental measurements, the $\mathrm{pH}$ over time. Compared with the purely stoichiometric model that adequately described the first minute of reaction, an effective prediction is obtained over a period of about 20 minutes on the basis of Equation (9).

For the above reasons, the parameters of Equation (8) $\left(k\right.$ hat, $\left.m_{f}\right)$ were fitted to the available experimental data. This equation appeared more efficient (rmse values lower than 0.013 ) for times less than or equal to $20 \mathrm{~min}$ (values obtained with $22 \mathrm{mmol}$ acetic acid) and simultaneously gave a fair prediction for longer reaction times (see Figure 4 for 22 and 24 mmol acetic acid).

Though formulated on the basis of empirical considerations, Equation 8 gives better results for data obtained at $22 \mathrm{mmol}$ with a simpler structure $\left(\mathrm{R}^{2}=0.99\right.$ for Equation 8 and $\mathrm{R}^{2}=0.97$ 
for Equation 9 if data at times $<30$ minutes are used, and $\mathrm{R}^{2}=0.98$ for Equation 8 and $\mathrm{R}^{2}$ of 0.86 for Equation 9 when all data available during the $6 \mathrm{~h}$ of reaction are used). These results were confirmed by all kinetic experimental data fitting and for all the acids we tested.

The $k$ hat values obtained for concentrations of 22 and $24 \mathrm{mmol}$ for acetic acid are 0.32 and $0.38(\mathrm{sg})^{-1}$ respectively, and $m_{f}$ values are 0.27 and $0.21 \mathrm{~g}$. The masses of minerals at $\mathrm{t}=0$ are 1.16 and $1.17 \mathrm{~g}$. For the five acids tested at $24 \mathrm{mmol}, k$ hat varies between 0.38 (acetic acid) and 0.5 (sg) ${ }^{-1}$ (citric acid), and $m_{f}$ lies between 0.21 (acetic acid) and 0 (citric acid). Assuming that $m_{f}$ is not dependent on temperature, and taking the value of $m_{f}$ obtained with different acids at $20^{\circ} \mathrm{C}, k$ hat should be multiplied by a factor of 2 to 2.5 to match the short-time prediction obtained for experimental data acquired at $40^{\circ} \mathrm{C}$.

A more complete formula could be proposed by replacing parameters $k$ hat and $m_{f}$ by simple functions involving molar ratio (MR), volume (V) and temperature (T). Integration of another parameter such as raw material size (S) is also desirable, as previously suggested by Le Roux et al. [2,44]. Equation 8 then takes the form:

$\frac{d m}{d t}=-\hat{k}(M R, V, S, T) \cdot\left(m-m_{f}(M R, V, S)\right) \cdot m$

This equation could be normalized to express the percentage of residual minerals (RM), and with all elements available Equation (11) is proposed for a fixed volume and raw material size:

$\frac{d z}{d t}=-k_{0} \cdot\left(\frac{M R}{M R+\alpha}\right) \cdot e^{-\frac{z_{s}}{R T}} \cdot\left(z-z_{f}\right) \cdot z \quad$ with $z(0)=100$ and $z_{f}=z_{0} \cdot e^{-\beta(M R-1)}$

Some of the elements needed to determine these two functions are already available in this work: for $5 \mathrm{~g}$ of dry cuticles, for a fixed volume of $50 \mathrm{ml}$, a cuticle piece size of between 500 microns and $1 \mathrm{~mm}$, and a temperature of $20^{\circ} \mathrm{C}$, Figures $3 \mathrm{~A}$ and $3 \mathrm{~B}$ enable us to sketch the $z_{f}$ function form (MR) . Under these conditions, it can be easily represented by exponential functions. On the basis of Figure 3A, for acetic acid, $z_{f}$ (MR) can be written:

$z_{f}(M R)=17.08 \cdot e^{-1.97 \cdot(M R 1)}$ 
On the basis of Figure 3B for formic acid, the function mf (MR) can be written:

$z_{f}(M R)=4.59 e^{-3.45(M R-1)}$

However, many additional experiments are needed for variables $\mathrm{V}, \mathrm{S}$ and $\mathrm{T}$ in both $k$ hat(MR,V,S,T) and $m_{f}(\mathrm{MR}, \mathrm{V}, \mathrm{S})$. Using the results presented in Table in supplemental materials for temperature and values obtained at 15 minutes for different molar ratio, we can obtain the following expressions:

$\frac{d z}{d t}=-0.0211 \cdot\left(\frac{M R}{M R+3.2}\right) \cdot e^{-\frac{4.33}{T}} \cdot\left(z-17.08 \cdot e^{-1.97 \cdot(M R-1))}\right) \cdot z$

for acetic acid, a raw material size of between 500 and 1000 micrometers for maximum length, a global reaction volume of $50 \mathrm{~mL}$, a molar ratio between 1.0 and 2.36 and a temperature between 20 and $40^{\circ} \mathrm{C}$, and

$\frac{d z}{d t}=-0.1134\left(\frac{M R}{M R+3.5}\right) \cdot e^{-\frac{3 t .54}{\tau}}\left(z-4.59 \cdot e^{-3.45(M R-1)}\right) \cdot z$

for formic acid, a raw material size of between 500 and 1000 micrometers for maximum length, a global reaction volume of $50 \mathrm{~mL}$, a molar ratio between 1.0 and 1.5 and a temperature between 20 and $40{ }^{\circ} \mathrm{C}$.

\section{Conclusions}

We have set the basis of a powerful empirical model (Equations 12 and 13) to meet our objectives: a cost and an energy balance, integrating the proposed optimal conditions, shows that, in a single-step process, hydrochloric acid can be used with enzymes with optimum activity at a pH equal or below 2.1 and citric acid can be coupled with enzymes with optimum activity at $\mathrm{pH}$ equal or below 3.1. Table 4 shows that in the presence of ASP enzyme, the objective of exceeding $95 \%$ deproteinization yield (PY), was not completely met. Formic acid presented many advantages and was the only acid tested that met our objectives (DY > $99 \%$, PY > 95 at maximum $\mathrm{pH}$ after $6 \mathrm{~h}$ ). It could serve to screen new 
enzyme activities whose optimum lies at a $\mathrm{pH}$ equal or below 3.5. Further work is needed to allow full formalized process optimization, especially in terms of demineralization kinetics modeling presented here. A forthcoming paper will extend the approach outlined here, focusing on the deproteinization process with the acid that offered, in the present work, the greatest benefit, namely formic acid.

An optimized process would need smaller amounts water and acids (meaning a solution with a higher $\mathrm{pH}$ ), which would come closer to fulfilling the requirements of a bio-refinery process. In these conditions, the recovered peptides could be more efficiently used for various purposes such as feed, food and nutraceuticals.

Acknowledgments: The authors thank Donnay-Moreno C. and Cornet J. for technical assistance. This work is included in the COSELMAR project with the financial support of Region Pays de la Loire (France) and Ifremer Institute. 


\section{References}

[1] F.A.O. The State of World Fisheries and Aquaculture. Food and Agriculture Organization of United Nations publication, Rome (2014)

[2] K. Le Roux. Purification de la chitine par hydrolyse enzymatique à partir de coproduits de crevette Penaeus vannamei. Caractérisations des produits et optimisation du procédé. Thèse de doctorat, Université de Nantes (2012),

[3] D. Raabe, C. Sachs, P. Romano, The crustacean exoskeleton as an example of a structurally and mechanically graded biological nanocomposite material, Acta Mater, 53 (15), (2005), 42814292.

[4] D. Raabe, P. Romano, Sachs C., Fabritius H., A. Al-Sawalmih, S. Yi, G. Servos, H.G. Hartwig, Microstructure and crystallographic texture of the chitin-protein network in the biological composite material of the exoskeleton of the lobster Homarus Americanus. Material Science Engineering A, 421 (2006), 143-153.

[5] J. F. V. Vincent, Arthropod cuticle: a natural composite shell system, Composites Part A, 33, (2002), 1311-1315.

[6] Le Roux K, Baron R, Arhaliass A, Leroy E, Bergé JP. Extraction of chitins in a single step by enzymatic hydrolysis in an acidic medium, US Patent US2014100361,2014-04-10.

[7] J. Ferrer, G. Paez, Z. Marmol, E. Ramones, H. Garcia, C.F. Forster, Acid hydrolysis of shrimpshell wastes and the production of single cell protein from the hydrolysate. Bioresource Technology, 57 (1996), 55-60.

[8] F. Shahidi, J. Synowiecki, Isolation and Characterization of Nutrients and Value-Added Products from Snow Crab (Chinoecetes opilio) and Shrimp (Pandalus borealis) Processing Discards, J. Agric. Food Chem., 39 (1991), 1527-1532.

[9] K.L. Chang, G. Tsai, Response Surface optimization and Kinetics of Isolating Chitin from Pink Shrimp (Solenocera melantho) Shell Waste. J. Agric. and Food Chem., 45 (1997), 1900-1904.

[10] O. Cremades, E. Ponce, R. Corpas, J.F. Guttierez, M. Jover, M.C. Alvarez-Ossorio, J. Parrado, J. Bautista. Processing of Crawfifh (Procambarus clarkii) for the Preparation of Carotenoproteins and Chitin. J. Agric. and Food Chem., 49(11) (2001), 5468-5472. 
[11] A. Gildberg, E. Stenberg, A new process for advanced utilization of shrimp waste, Process Biochem, 36 (2001), 809-812.

[12] M. Gimeno, J.Y. Ramirez-Hernandez, C. Martinez-Ibassa, N. Pachero, R. Garcia-Arrazola, E. Barzana, K. Shirai, One-Solvent Extraction of Asthaxanthin from Lactic Acid Fermented Shrimp Wastes. J. Agric. and Food Chem., 55(25) (2007), 10345-10350.

[13] J. Mojarrad, M. Nomati, H. Valizadeh, M. Ansarin, S. Bourbour, Preparation of glucosamine from exoskeleton of shrimp and predicting production yield by response Surface methodology. J. Agric. and Food Chem., 55(6) (2007), 2246-2250.

[14] A.D. Handayani, N. Indraswati, S. Suryadi Ismadji, Extraction of astaxanthin from giant tiger (Panaeus monodon) shrimp waste using palm oil: Studies of extraction kinetics and thermodynamic, Bioresource Technology 99 (2008), 4414-4419.

[15] L. Beaulieu, J. Thibodeau, P. Bryl, M.E. Carbonneau, Characterization of enzymatic hydrolyzed snow crab (Chionoecetes opilio) by-product fractions: A source of high-valued biomolecules. Bioresource Technology, 100 (13) (2009), 3332-3342.

[16] T.B. Cahu, S.D. Santos, A. Mendes, C.R. Cordula, S.F. Chavante, L.B. Carvalho Jr, H.B. Nader, R.S. Bezerra, Recovery of protein, chitin, carotenoids and glycosaminoglycans from Pacific white shrimp (Litopenaeus vannamei) processing waste Process Biochem, 47(2012), 570-577.

[17] M. R. Kumar, A review of chitin and chitosan applications. Reactive and Functional Polymers 46(2000), 1-27.

[18] J. Synowiecki, N.A.A.Q. Al-Khateeb, The recovery of protein hydrolysate during enzymatic isolation of chitin from shrimp Crangon crangon processing discards. Food Chemistry 68(2000), 147-152.

[19] B. Krajewska, Application of chitin- and chitosan-based materials for enzyme immobilizations: a review. Enzyme Microbiol. Technol. 35(2004), 126-39.

[20] M. Rinaudo, Chitin and chitosan: Properties and applications. Prog. Polym. Sci, 31(2006), 603632.

[21] F. Shahidi, J.K.V. Arachchi, Y.J. Jeon,. Food applications of chitin and chitosans. Trends in Food Science \& Technology, 10(1999), 37-51. 
[22] I. Aranaz, M. Mengibar, R. Harris, I. Panos, B. Miralles, N. Acosta, G. Galed, A. Heras, Functional characterization of chitin and chitosan. Current Chemical Biology, 3(2) (2009), 203230.

[23] E. Abdou, K. Nagy, M. Elsabe,. Extraction and characterization of chitin and chitosan from local sources. Bioresource Technology, 99 (2008), 1359-1367.

[24] K. Kurita, Chitin and chitosan: Functional biopolymers from marine crustaceans. Marine Biotechnology, 8(3) (2006), 203-226.

[25] G.H. Jo, W.J. Jung, J.H. Kuk, K.T. Oh, Y.J. Kim, R.D. Park, Screening of protease-producing Serratia marcescens FS-3 and its application to deproteinization of crab shell waste for chitin extraction. Carbohydrate Polymers, 74(2008), 504-508.

[26] R.H. Rødde, A. Einbu, K. Varum, A seasonal study of the chemical composition and chitin quality of shrimp shells obtained from northern shrimp (Pandalus borealis). Carbohydrate Polymers 71(2008), 388-393.

[27] L. Fusi, A. Monti, M. Primicerio, Determining calcium carbonate neutralization kinetics from experimental laboratory data. J. Math Chem., 50(2012), 2492-2511.

[28] V.F. Abdullin, S.E. Artemenko, G.P. Ovchinnnikova, O.S.Arzamastsev, Extraction Processes in Extraction of the Biopolymer Chitin from Crab Shells. Fibre Chemistry, 40(6) (2008), 513-516.

[29] A. Percot, C. Viton, A. Domard, Optimization of Chitin Extraction from Shrimp Shells, Biomacromolecules, 4 (2003), 12-18.

[30] F.A. Al Sagheer, M.A. Al-Sughayer, S. Muslim, M.Z. Elsabee, Extraction and characterization of chitin and chitosan from marine sources in Arabian Gulf. Carbohydrate Polymers, 77 (2009), 410-419.

[31] S.-L. Wang, T.-W. Liang, Y.-H. Yen, Bioconversion of chitin-containing wastes for the production of enzymes and bioactive materials. Carbohydrate Polymers, 84(2) (2011), 732-742.

[32] H.L. Casal, U. Kohler, H.H. Mantsch, Structural and conformational changes of betalactoglobulin B: an infrared spectroscopic study of the effect of $\mathrm{pH}$ and temperature. Biochimica et Biophysica Acta, 957(1988), 11-20. 
[33] K.A. Dill and D. Shortle, Denatured states of proteins. Annual Review of Biochemistry, 60(1991), 795-825.

[34] R.S. Bezerra, E.J.F. Lins, R.B. Alencar, P.M.G. Paiva, M.E.C. Chaves, L.C.B.B. Coelho, Alkaline proteinase from intestine of Nile tilapia (Oreochromis niloticus, L.) feeds. Process Biochem, 40 (2005), 1829-1834.

[35] A. Guillou, M. Khalil, L. Adambounou, Effects of silage preservation on astaxanthin forms and fatty acid profiles of processed shrimp (Pandalus borealis) waste. Aquaculture, 130(1995), 35160.

[36] N. Gagne and B.K. Simpson, Use of proteolytic enzymes to facilitate the recovery of chitin from shrimp waste. Food Biotechnol., 7(1993), 253-63.

[37] W.J. Jung, J.H. Kuk, K.Y. Kim, R.D. Park, Demineralization of red crab shell waste by lactic acid Fermentation. Appl. Microbiol. Biotechnol. 67 (2005), 851-854.

[38] N. Pacheco, M. Garnica-González, J. Ramírez-Hernández, B. Flores-Albino, M. Gimeno, E. Bárzana, K. Shirai, Effect of temperature on chitin and astaxanthin recoveries from shrimp waste using lactic acid bacteria. Bioresource Technology, 100 (11) (2009), 2849-2854.

[39] L. Manni, O. Ghorbel-Bellaaj, K. Jellouli, I. Younes, M. Nasri, Extraction and Characterization of Chitin, Chitosan and Protein Hydrolysates Prepared from Shrimp Waste by Treatment with Crude Protease from Bacillus cereus SV1. Appl Biochem Biotechnol 162 (2010), 345-357.

[40] G.T. Kjartansson, S. Zivanovic, K. Krittoergsson, J. Weiss, Sonication-assisted extraction of chtin from shells of fresh water prawns (Macrobrachium rosenbergii). J. Agric. and Food Chem., 54(9) (2006a), 3317-3323.

[41] G.T. Kjartansson, S. Zivanovic, K. Krittoergsson, J. Weiss, Sonication-assisted extraction of chtin from North Atlantic Shrimps (Pandelus Borealis). J. Agric. and Food Chem., 54(16) (2006b), 5894-5902.

[42] T. Wu, S. Zivanovic, D.G. Hayes, J. Weiss, Efficient reduction of chitosan molecules weight by high intensity ultrasounds underlaying mechanism and effect of process parameters. J. Agric. and Food Chem., 56(13) (2008), 5112-5119. 
[43] X. Cui, J. Sun, X. Li, J. Wang, H. Wang, Optimization for Ultrasound-assisted Calcium Hydroxide Extraction of Protein from Shrimp Waste using Response Surface Methodology. Adv. J. of Food Sci. and Techn., 6(2) (2014), 228-232.

[44] K. Le Roux, A. Arhaliass, R. Baron, J.P. Bergé, New enzymatic extraction of chitin from marine by-products. Proceedings of 9th Asia-Pacific Chitin \& Chitosan Symposium, (2011), 73-80.

[45] AOAC. Official method of analysis of the Association of Official Analytical Chelist. AOAC International: Arlington (USA), N934-06, 1990.

[46] L.M.P. Valente, J. Cornet, C. Donnay-Moreno, J.P. Gouygou, J.P. Berge, M. Bacelar, M. Cardinal, Quality differences of gilthead sea bream from distinct production systems in Southern Europe: Intensive, integrated, semi-intensive or extensive systems. Food Control, 22(5) (2011), 708-717.

[47] R.E. Notari, T.D. Sokoloski, Kinetics of calcium carbonate neutralization. J. Pharm. Sci. 54(10)(1965), 1500-1504. 


\section{Figure Captions}

Figure 1. Percentage of residual minerals as a function of reaction time for the five acids investigated for cuticle demineralization kinetics at $20^{\circ} \mathrm{C}$ : acetic, formic, citric, phosphoric and hydrochloric acids. The same quantity (24 mmole, considered stoichiometric, adjusted for a bulk solution volume of $50 \mathrm{~mL}$ ) of each acid was used with $5 \mathrm{~g}$ of shell containing $1.17 \pm 0.05 \mathrm{~g}$ minerals. The experimental values are connected by predictable lines (cubic spline interpolations) to guide the reader.

Figure 2. A) $\mathrm{pH}$ variation in time at $20^{\circ} \mathrm{C}$ with $22 \mathrm{mmole}$ acetic acid in a total volume of $50 \mathrm{~mL}$. (pink diamonds) for shrimp shell, and (blue circles) for calcium carbonate powder in the same conditions a). Insert 1: Zoom image for the first 2 minutes of reaction.

B) Theoretical estimation and experimental determination of residual mineral quantity as a function of reaction time for cuticle demineralization with acetic acid at $20{ }^{\circ} \mathbf{C}$. Estimation from Equations 1 and 2, for $5 \mathrm{~g}$ of the shrimp shell containing 1.17 \pm 0.05 g minerals reacting with 22 mmole acetic acid in a volume of $50 \mathrm{~mL}$ (red dashdotted line). Estimation from Equations 1 and 2 for $1.16 \mathrm{~g}$ of $\mathrm{CaCO}_{3}$ powder reacting with 22 mmole acetic acid in a final volume of $50 \mathrm{~mL}$ (blue dashed line). Experimental data of residual minerals when 5 g of shrimp shell react with 22 mmole acetic acid in a final volume of $50 \mathrm{~mL}$ (black stars) Insert 1: Zoom for of the first 2 minutes of reaction.

Figure 3. Percentage of residual minerals and solutions pH values after $6 \mathrm{~h}$ of reaction at $20{ }^{\circ} \mathrm{C}$ for several initial concentrations of acids: a) acetic acid and b) formic acid. The initial molar ratio (acid/minerals) was calculated by referring to the quantity of minerals in $5 \mathrm{~g}$ of shell (the ratio of one corresponds to $0.47 \mathrm{M}$ acid solution for a pre- 
defined volume of $50 \mathrm{~mL}$ ). Blue triangle in $\mathbf{A}$ and blue stars in $\mathbf{B})$, represent the percentage of residual minerals. Green circles in A) and green triangles in B), represent the $\mathrm{pH}$ of the solution.

Figure 4. Model parameter fitting. Experimental data for $22 \mathrm{mmol}$ (black asterisk) and 24 mmol (black circles) acetic acid and curve fitting by means of Equation 4 (blue dashed line) and Equation 5 (green solid line $22 \mathrm{mmol}$ and green dash-dot line $24 \mathrm{mmol}$ ). Insert: Zoom on 20 minutes of reaction. 


\section{Tables}

Table 1. Synthesis of results for formic acid and acetic acid on averaged residual minerals, $\mathrm{pH}$ and averaged residual proteins (at final time) with or without presence of ASP enzyme at three times (9, 15 and 360 minutes) and three temperatures (20, 30 and $40{ }^{\circ} \mathrm{C}$ ).

\begin{tabular}{|c|c|c|c|c|c|c|c|c|}
\hline \multicolumn{9}{|c|}{ Formic acid at $24 \mathrm{mmol}$ in a total volume of $50 \mathrm{ml}$} \\
\hline & & \multicolumn{2}{|l|}{$t=9 \min$} & \multicolumn{2}{|l|}{$t=15 \mathrm{~min}$} & \multicolumn{3}{|l|}{$t=360 \mathrm{~min}$} \\
\hline Temperature & & $\begin{array}{l}\text { Averaged } \\
\text { residual } \\
\text { minerals (\%) }\end{array}$ & $\mathrm{pH}$ & $\begin{array}{l}\text { Averaged } \\
\text { residual } \\
\text { minerals (\%) }\end{array}$ & $\mathrm{pH}$ & $\begin{array}{l}\text { Averaged } \\
\text { residual } \\
\text { minerals (\%) }\end{array}$ & $\mathrm{pH}$ & $\begin{array}{l}\text { Averaged } \\
\text { residual proteins } \\
(\%)\end{array}$ \\
\hline & $\begin{array}{l}\text { With enzyme } \\
\text { (ASP) }\end{array}$ & $11.3 \pm 0.8$ & 3.61 & $8.8 \pm 0.7$ & 4.10 & $4.1 \pm 0.4$ & 4.32 & $6.1 \pm 0.8$ \\
\hline $40^{\circ} \mathrm{C}$ & Without enzyme & $13.0 \pm 0.9$ & 3.60 & $9.0 \pm 0.8$ & 4.08 & $3.7 \pm 0.4$ & 4.33 & $71.0 \pm 8.0$ \\
\hline $30^{\circ} \mathrm{C}$ & $\begin{array}{l}\text { With enzyme } \\
\text { (ASP) }\end{array}$ & $16.1 \pm 1.3$ & 3.74 & $11 \pm 0.9$ & 3.83 & $3.9 \pm 0.4$ & 4.38 & $24.2 \pm 3.0$ \\
\hline $20^{\circ} \mathrm{C}$ & $\begin{array}{l}\text { With enzyme } \\
\text { (ASP) }\end{array}$ & $24.3 \pm 2.0$ & 3.89 & $17.1 \pm 1.4$ & 3.97 & $4.1 \pm 0.4$ & 4.45 & $49.2 \pm 5.0$ \\
\hline \multicolumn{9}{|c|}{ Acetic acid at $24 \mathrm{mmol}$ in a total volume of $50 \mathrm{ml}$} \\
\hline & & \multicolumn{2}{|l|}{$t=9 \min$} & \multicolumn{2}{|l|}{$t=15 \min$} & \multicolumn{3}{|l|}{$t=360 \min$} \\
\hline Temperature & & $\begin{array}{l}\text { Averaged } \\
\text { residual } \\
\text { minerals (\%) }\end{array}$ & $\mathrm{pH}$ & $\begin{array}{l}\text { Averaged } \\
\text { residual } \\
\text { minerals (\%) }\end{array}$ & $\mathrm{pH}$ & \begin{tabular}{|l} 
Averaged \\
residual \\
minerals (\%)
\end{tabular} & $\mathrm{pH}$ & $\begin{array}{l}\text { Averaged } \\
\text { residual proteins } \\
(\%)\end{array}$ \\
\hline & $\begin{array}{l}\text { With enzyme } \\
\text { (ASP) }\end{array}$ & $28.1 \pm 2.1$ & 4.51 & $22.3 \pm 1.7$ & 4.54 & $16.3 \pm 1.2$ & 4.89 & $7.5 \pm 1.0$ \\
\hline $40^{\circ} \mathrm{C}$ & Without enzyme & $28.9 \pm 2.0$ & 4.46 & $22.0 \pm 1.6$ & 4.52 & $16.7 \pm 1.2$ & 4.90 & $68.0 \pm 8.0$ \\
\hline $30^{\circ} \mathrm{C}$ & $\begin{array}{l}\text { With enzyme } \\
\text { (ASP) }\end{array}$ & $29.2 \pm 2.2$ & 4.55 & $23.2 \pm 2.0$ & 4.60 & $17.1 \pm 1.1$ & 4.95 & $29.7 \pm 3.0$ \\
\hline $20^{\circ} \mathrm{C}$ & $\begin{array}{l}\text { With enzyme } \\
\text { (ASP) }\end{array}$ & $31.8 \pm 2.7$ & 4.61 & $25.8 \pm 2.4$ & 4.71 & $16.4 \pm 1.4$ & 4.96 & $52.4 \pm 5.0$ \\
\hline
\end{tabular}


Table 2. Initial and final (after $6 \mathrm{~h}$ of reaction) $\mathrm{pH}$ of the solution and percentage of residual minerals for the five acids tested in the same experimental conditions as presented in Figure 1.

\begin{tabular}{|c|c|c|c|c|c|}
\hline Acid $\left(p K_{\mathrm{a}}\right)$ & $\begin{array}{l}\text { Acetic } \\
(4.76)\end{array}$ & $\begin{array}{l}\text { Formic } \\
(3.75)\end{array}$ & $\begin{array}{l}\text { Citric } \\
(3.1)\end{array}$ & $\begin{array}{l}\mathrm{H}_{3} \mathrm{PO}_{4} \\
(2.1)\end{array}$ & $\begin{array}{l}\text { HCl } \\
(-)\end{array}$ \\
\hline Initial pH & 2.48 & 2.14 & 1.87 & 1.38 & 0.30 \\
\hline Final pH & 4.96 & 4.45 & 3.10 & 3.30 & 2.54 \\
\hline Averaged residual & $16.4 \pm 1.1$ & $4.1 \pm 0.3$ & $1.0 \pm 0.1$ & $7.0 \pm 0.5$ & $1.4 \pm 0.1$ \\
\hline Minerals (\%) & & & & & \\
\hline
\end{tabular}


Table 3. Residual minerals RM (\%) and $\mathrm{pH}$ for different volume at $20^{\circ} \mathrm{C}$ and a molar ratio of 1.03 (stochiometric condition -24 mmol of acid added) for formic acid and acetic acid (* approximation of error by calculation).

\begin{tabular}{|c|c|c|c|c|}
\hline \multicolumn{5}{|l|}{ Formic acid } \\
\hline Volume (ml) & $\begin{array}{c}\text { Residual minerals } \\
\text { RM }(\%) \\
\text { at } t=15 \mathrm{~min}\end{array}$ & $\begin{array}{c}\mathrm{pH} \\
\text { at } t=15 \mathrm{~min}\end{array}$ & $\begin{array}{c}\text { Residual minerals } \\
\text { RM (\%) } \\
\text { at } t=360 \mathrm{~min}\end{array}$ & $\begin{array}{c}\mathrm{pH} \\
\text { at } t=360 \mathrm{~min}\end{array}$ \\
\hline 50 & $17.4 \pm 1.7^{*} \%$ & 4.01 & $4.1 \pm 0.4 \%$ & $4.48 \pm 0.4$ \\
\hline 250 & $31.8 \pm 3.2^{*} \%$ & 3.79 & $3.7 \pm 0.3 \%$ & $4.51 \pm 0.4$ \\
\hline \multicolumn{5}{|l|}{ Acetic acid } \\
\hline Volume (ml) & $\begin{array}{c}\text { Residual minerals } \\
\mathrm{RM}(\%) \\
\text { at } t=15 \mathrm{~min}\end{array}$ & $\begin{array}{c}\mathrm{pH} \\
\text { at } t=15 \mathrm{~min}\end{array}$ & $\begin{array}{c}\text { Residual minerals } \\
\mathrm{RM}(\%) \\
\text { at } t=360 \mathrm{~min}\end{array}$ & $\begin{array}{c}\mathrm{pH} \\
\text { at } t=360 \mathrm{~min}\end{array}$ \\
\hline 50 & $26.1 \pm 2.6^{*} \%$ & 4.78 & $16.4 \pm 1.4 \%$ & $4.96 \pm 0.3$ \\
\hline 250 & $45.2 \pm 4,5^{\star} \%$ & 5.28 & $9.4 \pm 1,2 \%$ & $5.28 \pm 0.3$ \\
\hline
\end{tabular}


Table 4. Conditions giving demineralization yields exceeding 99\% in a 6 h one-step enzymatic acidic hydrolysis of $5 \mathrm{~g}$ of shrimp cuticle (* approximation of error by calculation).

\begin{tabular}{|c|c|c|c|c|c|}
\hline Acid $\left(p K_{a}\right)$ & Acetic (4.76) & $\begin{array}{c}\text { Formic } \\
(3.75)\end{array}$ & Citric (3.1) & $\begin{array}{c}\text { Phosphoric } \\
\text { (2.1) }\end{array}$ & Hydrochloric (-) \\
\hline $\begin{array}{l}\text { Molar ratio } \\
\text { (acid/minerals) }\end{array}$ & 2.36 & 1.50 & 1,00 & 1.50 & 1.10 \\
\hline $\begin{array}{l}\text { Solution volume } \\
\text { (mL) }\end{array}$ & 50 & 50 & 50 & 50 & 50 \\
\hline $\begin{array}{l}\text { Residual minerals } \\
(t=360 \text { min }) \text { at } \\
20{ }^{\circ} \mathrm{C} \text { without } \\
\text { enzyme } \\
\text { pH }(t=360 \mathrm{~min}) \text { at } \\
20{ }^{\circ} \mathrm{C} \text { without } \\
\text { enzyme }\end{array}$ & $\begin{array}{c}1.00 \pm 0.1 * \% \\
3.60\end{array}$ & $\begin{array}{c}0.95 \pm 0.1 * \% \\
3.50\end{array}$ & $\begin{array}{c}1.00 \pm 0.1 * \% \\
3.10\end{array}$ & $\begin{array}{c}0.96 \pm 0.1 * \% \\
2.50\end{array}$ & $\begin{array}{c}0.90 \pm 0.1 * \% \\
2.10\end{array}$ \\
\hline $\begin{array}{l}\text { Residual minerals } \\
(t=360 \text { min }) \text { at } \\
40{ }^{\circ} \mathrm{C} \text { with ASP } \\
\text { enzyme } \\
\text { pH }(t=360 \text { min }) \text { at } \\
40{ }^{\circ} \mathrm{C} \text { with ASP } \\
\text { enzyme } \\
\text { Residual proteins } \\
(t=360 \text { min }) \text { at } 40 \\
{ }^{\circ} \mathrm{C} \text { with ASP } \\
\text { enzyme }\end{array}$ & $0.94 \pm 0.1 \%$ & $0.90 \pm 0.1 \%$ & 2.90 & $0.95 \pm 0.1 \%$ & $0.90 \pm 0.1 \%$ \\
\hline
\end{tabular}


Figure 1

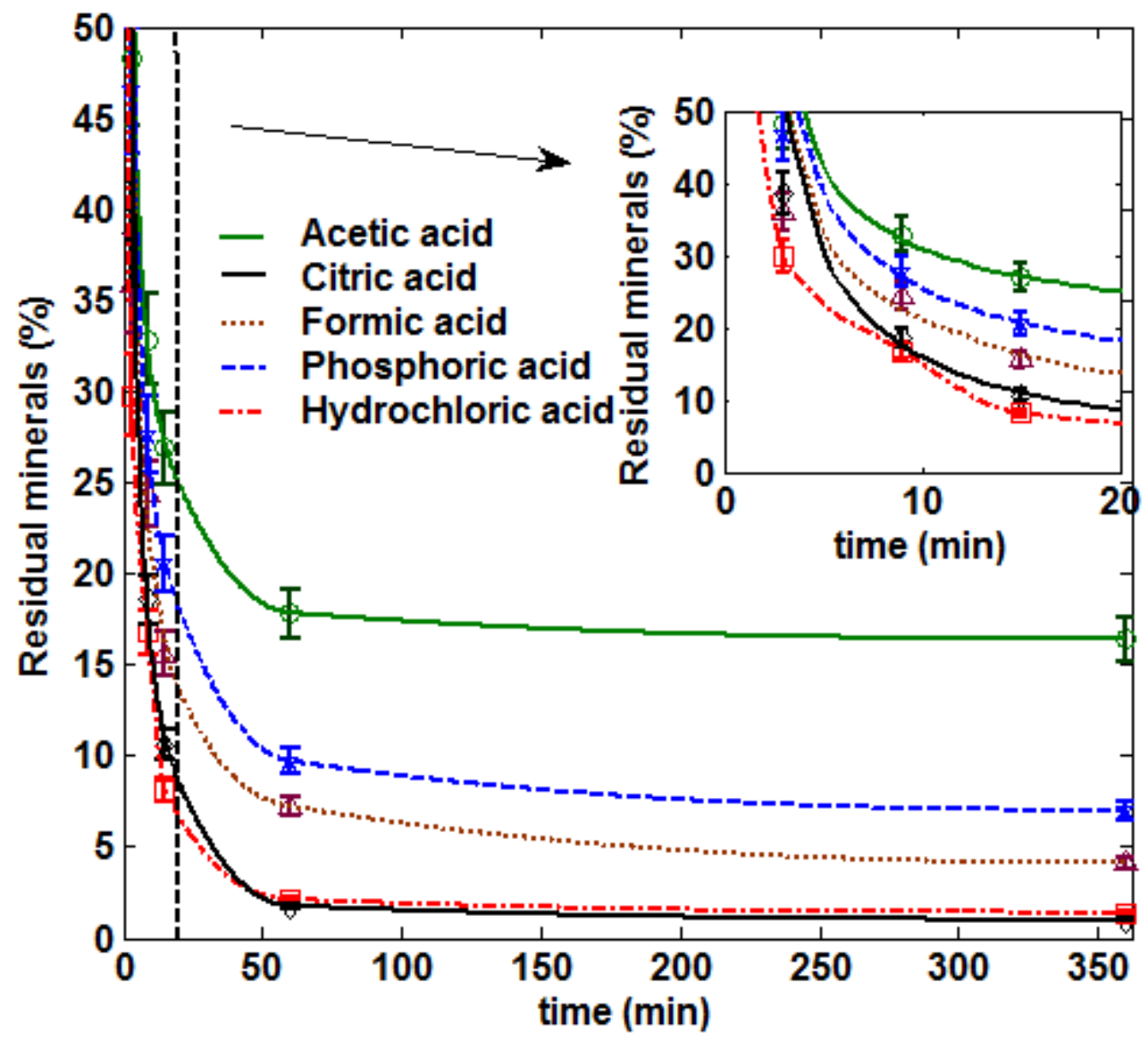


Figure 2

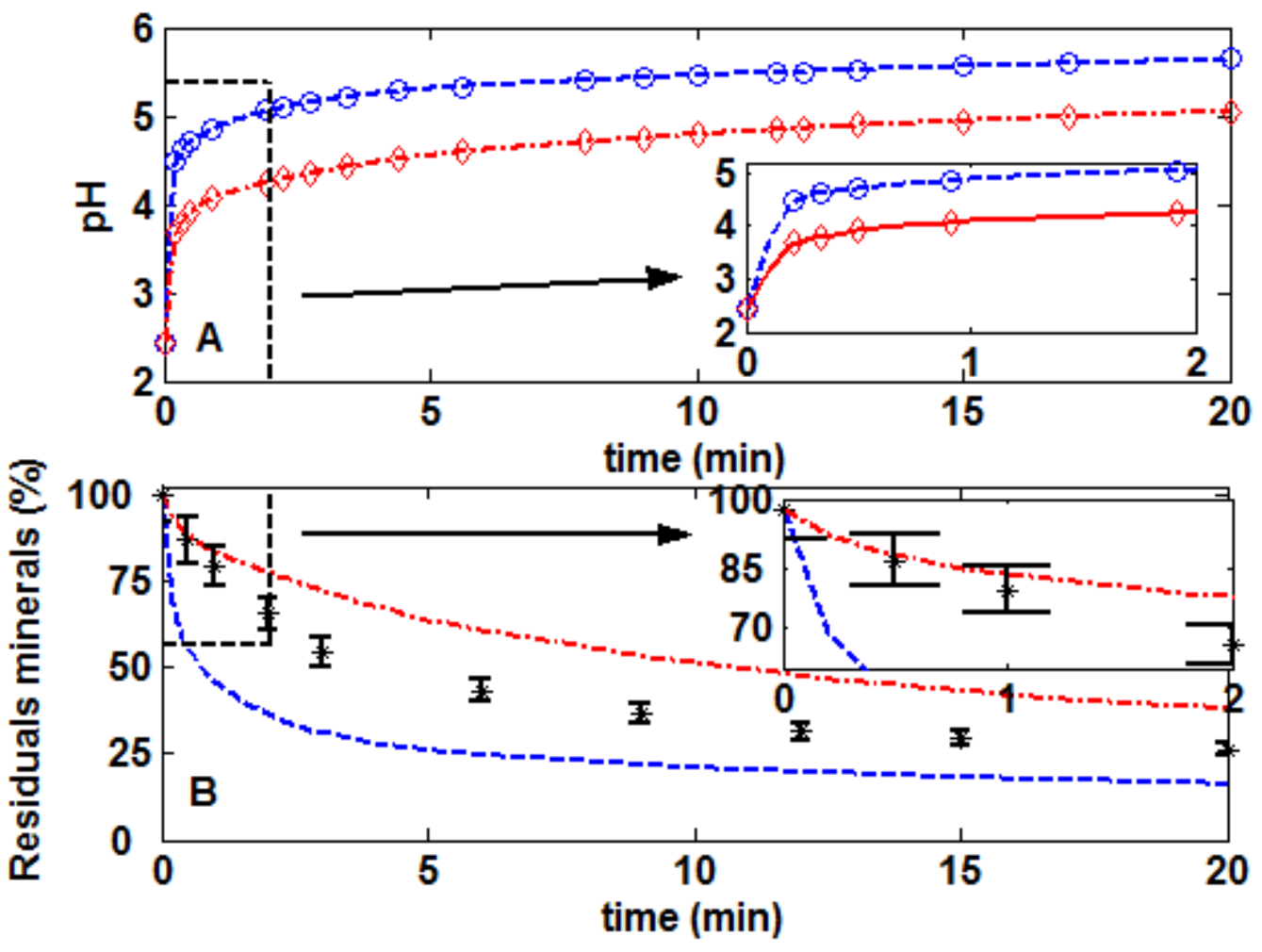


Figure 3
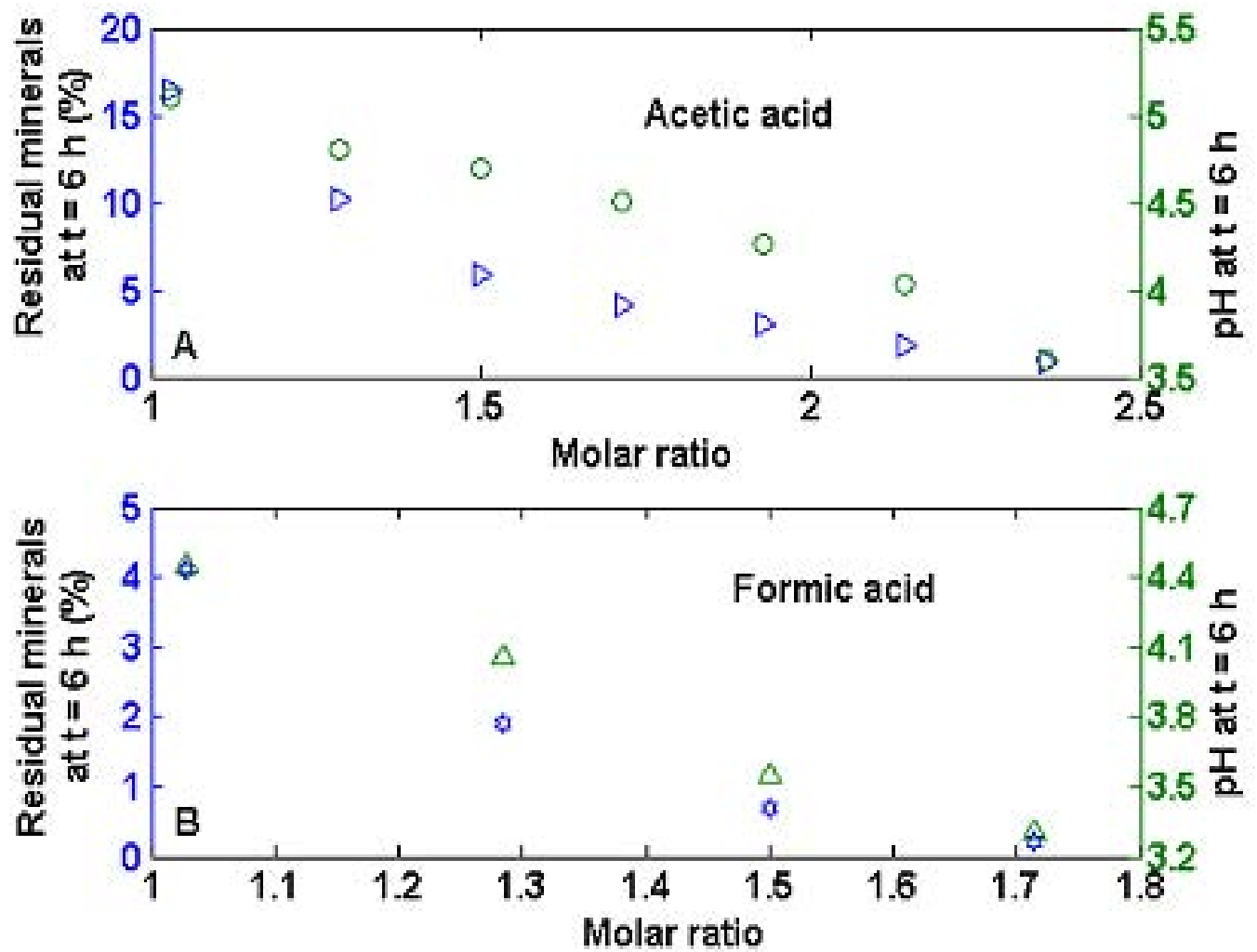
Figure 4

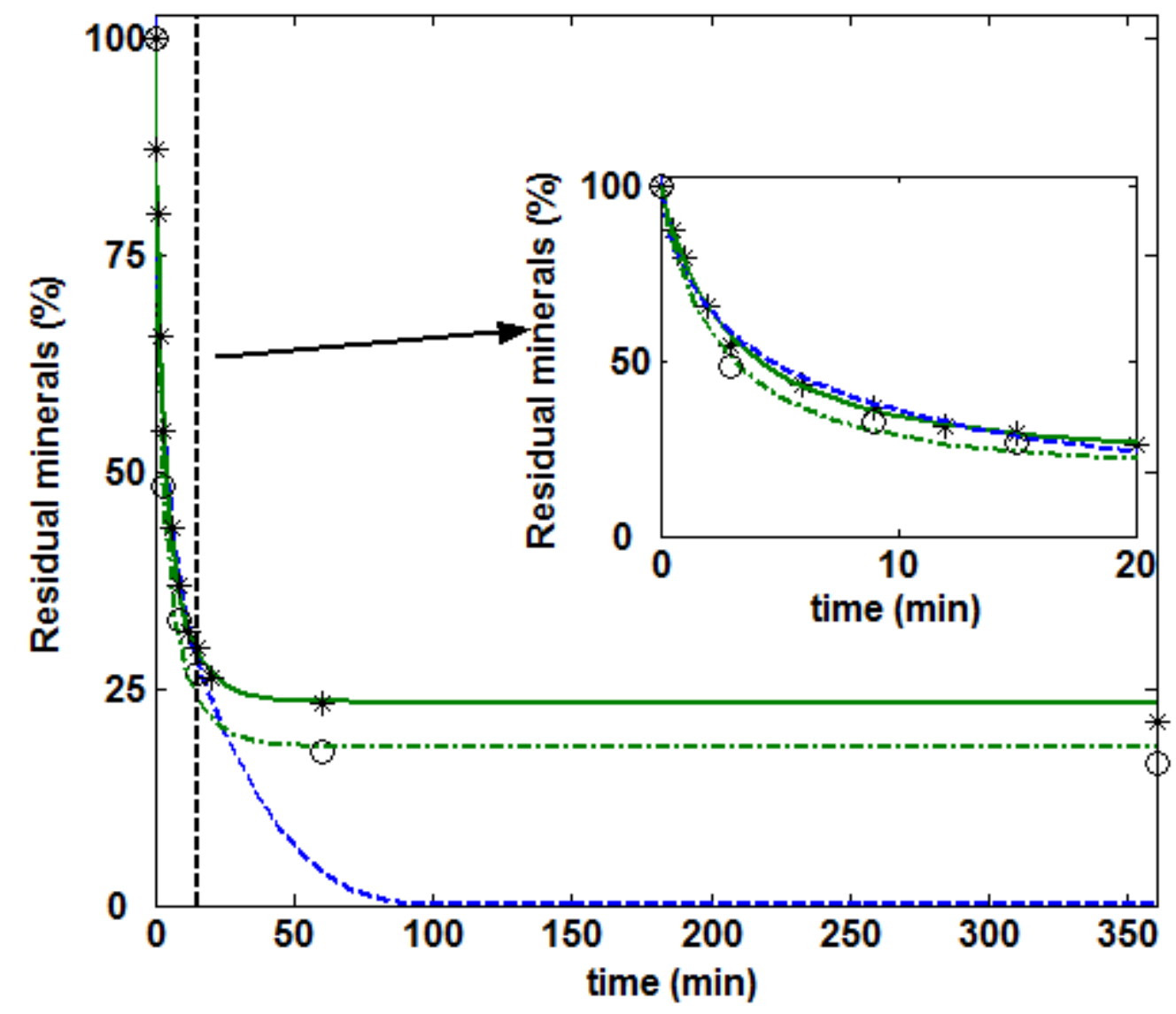




\section{Supplemental materials}

Table 1 - Description of the experimental design presented in this paper 
All experiments in an acid medium were carried out with $5.0 \mathrm{~g}$ of crushed dried shrimp shells of size between 0.5 and $1 \mathrm{~mm}$.

The experiments are numbered from E0 to E76. The number of repeats is indicated in brackets, if it is omitted then no repeat was done.

Several experiments were repeated to analyze the influence of different parameters, in this case this appears in italics.

The initial composition of the raw material was determined previously [2]. It indicates $1.17 \mathrm{~g}$ minerals for $5.0 \mathrm{~g}$ of dried shrimp. Analysis of the proportion of $\mathrm{CaCO}_{3}$ by SEM / EDX- E0 (5 repeats)

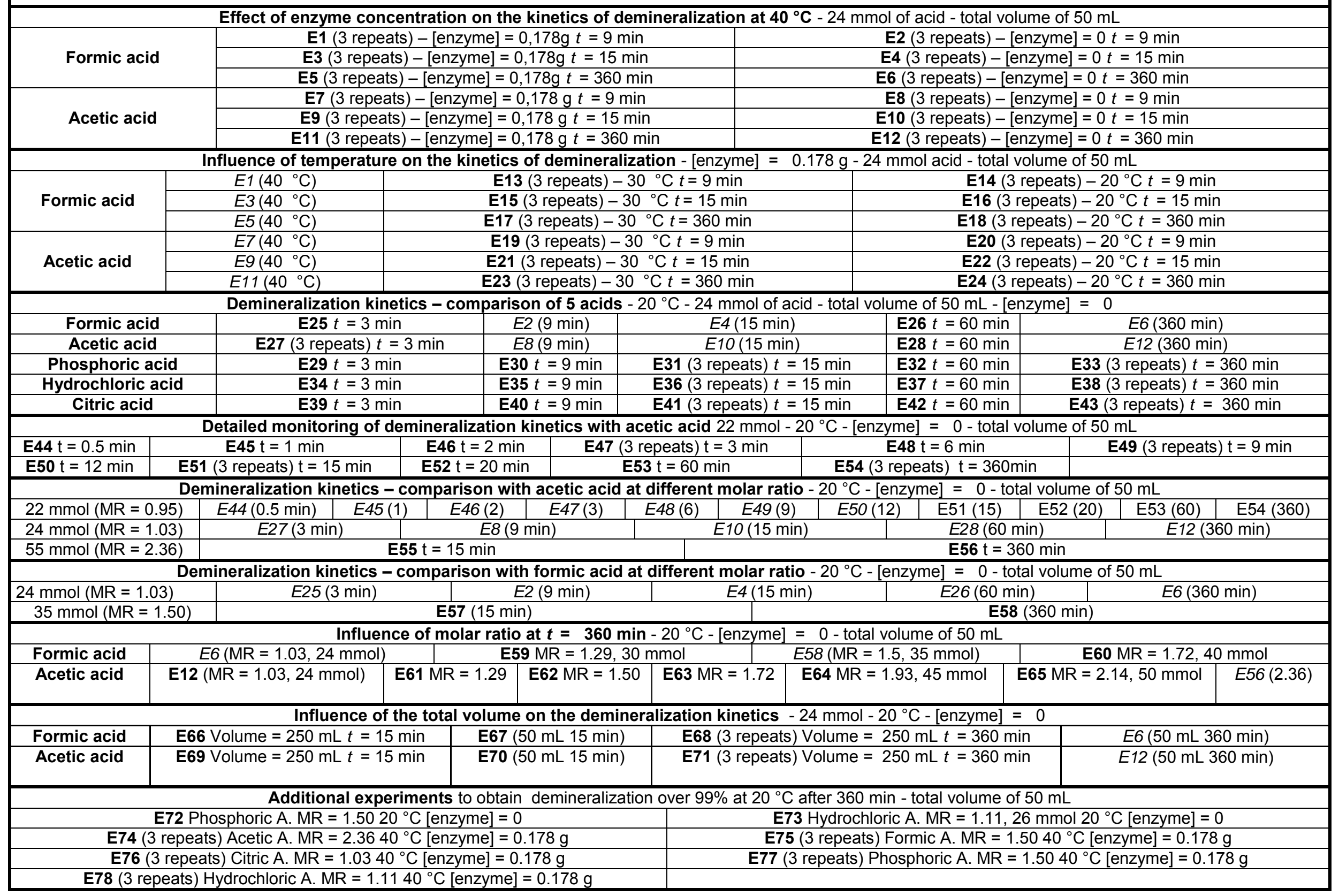

